\title{
Vitrectomy, inner limiting membrane peel and gas tamponade in the management of traumatic paediatric macular holes - A case series of 13 patients
}

Nicholas Brennan, Ian Reekie, Anthony Khawaja, Nikolaos Georgakrakos, Eric Ezra

\begin{abstract}
:
Purpose: To review the outcomes of vitrectomy, inner limiting membrane (ILM) peel and gas tamponade in the management of traumatic macular holes in paediatric cases.

Methods: Retrospective review of a consecutive case series of paediatric cases undergoing vitrectomy, ILM peel and gas tamponade between March 2007 and July 2014 by a single surgeon. Main outcome measures: visual outcome, anatomic closure rate and ocular complications.

Results The macular hole was successfully closed in 12 (92.3\%) of the 13 cases identified. Mean visual acuity pre-operatively was 0.93 LogMar improving to 0.54 LogMar at three months and 0.48 LogMar at twelve months. This was statistically significant $(P<0.001)$. There were no intraoperative complications. One patient developed a posterior subcapsular cataract 12 months after surgery.
\end{abstract}

Conclusion: Vitrectomy and ILM peel have been successful in the treatment of paediatric macular holes. The procedure is efficacious and comparable to plasminassisted vitrectomy. 


\section{Introduction:}

Macular holes may develop as either idiopathic lesions or due to physical trauma. Unlike adult macular holes, those occurring in children are very rare and are mostly traumatic in aetiology, though rare exceptions have been documented ${ }^{11}$. At present the optimum management of macular holes in paediatric populations has not been ascertained; the rarity of paediatric macular holes means that the techniques reported in the literature are largely in the form of single patient case reports or case series. Three such case series each include 4 patients; Azevedo and colleagues report 4 paediatric patients treated with pars planar vitrectomy and internal limiting membrane peel, all of whom had a successful hole closure ${ }^{[2]}$. Likewise Wachtlin et al report $100 \%$ hole closure and substantial visual improvement in each of their 4 patients after vitrectomy and ILM peel with use of autologous platelet injection ${ }^{[3]}$. A further series of 4 patients reported by Margherio et al were managed differently, with autologous plasmin injection prior to vitrectomy ${ }^{[4]}$.

We present a series of thirteen consecutive cases of paediatric traumatic macular holes treated by vitrectomy and internal limiting membrane (ILM) peel at Moorfields eye hospital and review the outcomes of these cases, which form one of the largest series of its kind in the literature. We focus on the efficacy of vitrectomy and ILM peel in restoring visual function and producing closure of the macular defect.

\section{Methodology:}

All patients eighteen years of age and younger who underwent vitrectomy between March 2007 and July 2014 were identified on the Moorfields electronic database. Those cases meeting the following inclusion criteria were reviewed:

- Traumatic macular hole

- Surgical intervention with a vitrectomy and inner limiting membrane peel.

- Full patient demographics available

- Nature of the trauma known

- Pre-operative and post operative visual acuity at 3 and 12 months known

- Documentation from clinical examination or Optical Coherence Tomography of hole closure status

SURGICAL METHOD

STATISTICS

\section{Results:}


Thirteen consecutive cases undergoing vitrectomy and ILM peel for traumatic macular hole were identified. The patient profiles are depicted in Table 1. Two cases had co-existent ocular trauma; 360 degree angle recession and zonular weakness with iridodenesis. The interval from trauma to surgery ranged from 28 days to 12 months, with a mean of 5.5 months. Surgery was performed by a single surgeon and gas tamponade was C3F8 14\% in all cases. In only one patient was a posterior vitreous detachment (PVD) present pre-operatively with the remainder having a surgically induced PVD. No intraoperative complications were reported and specifically no intraoperative iatrogenic retinal breaks. Post operative complications included cataract in one case. No other complications had been reported at 12 months post surgery.

The mean pre-operative visual acuity was LogMar 0.93 which improved to LogMar 0.54 at three months and LogMar 0.45 at 12 months $(P<0.001)$.

\section{Discussion:}

Adult macular holes are a relatively common ophthalmological condition with an estimated incidence of $7.8 / 100000$ per year ${ }^{[5]}$. They are most commonly idiopathic age related conditions that have a greater incidence in females than males ${ }^{[2]}$. They do also occur much more rarely in children, where they most commonly develop after trauma.

The mechanism of development of a macular hole after trauma is not entirely clear. It has been suggested that vitreous detachment and subsequent traction on the macular region may be causative, however in many cases the vitreous is still firmly adherent to the retina and an alternative mechanism would therefore seem likely such as direct rupture of the fovea due to transmitted force of impact. Other suggested pathogenic mechanisms, based on OCT examination of a developing macular hole include the degeneration of cystoid macular oedema, sub-foveal haemorrhage, contusion necrosis and choroidal rupture as well as sub-clinical changes to the fovea $[2,6,7]$. The internal limiting membrane of the retina has been hypothesised to produce traction on the edges of the macular hole and therefore to help keep it open. This provides the rational for ILM peeling as part of the surgical repair of a macular hole along with vitrectomy ${ }^{[8]}$.

Currently the best practice in management of paediatric macular holes has not been defined by clinical trials; the rarity of paediatric holes means that conducting such a trial would be technically difficult to organise and therefore individual cases and case series thus far provide the evidence base for treatment decisions. Vitrectomy is used as the backbone of all treatments with various additional adjuvant techniques 
suggested as beneficial by different authors. It has been noted that macular holes may spontaneously close in some patients, and therefore a period of watchful waiting has been advised by some ${ }^{[9]}$. However, at younger ages there is a risk of amblyopia developing due to reduced visual acuity caused by a macular hole ${ }^{[4]}$, meaning that conservative management even for a short amount of time is not a risk free strategy. A key difference between the eye in childhood and adolescence and that of the adult is the strength of attachment between the vitreous and the ILM; at younger ages the adhesion is strong ${ }^{[10]}$ which makes creating a posterior vitreous detachment during surgery a challenge in the paediatric patient. There have been several case series where autologous plasmin injection during surgery has been used to aid the creation of a clear separation between the vitreous and the retina, with good macular hole closure and visual results reported ${ }^{[2,11]}$. Autologous plasmin, and more recently a recombinant variant, is increasingly used in several adult and paediatric vitreoretinal surgeries ${ }^{[12]}$.

Most paediatric case series reported up until this point have described single figure numbers of patients and without high quality randomised controlled trials it is not possible to confirm which management strategy provides the best visual outcomes. Azevedo and colleagues discuss the use of pars planar vitrectomy and internal limiting membrane peel in the successful closure of 4 paediatric macular holes, providing a substantial improvement in vision in 3 cases ${ }^{[2]}$. Wachtlin et al report 4 further patients managed by vitrectomy, ILM peel with the additional use of autologous platelet injection, again hole closure was universal and 2 of the 4 patients achieved vision of better than 20/50 in the damaged eye ${ }^{[3]}$. A further series of 4 patients reported by Margherio et al were managed by vitrectomy with autologous plasmin injection, hole closure was again achieved in each of these patients and 3 achieved vision of better than $20 / 50$, though three also went on to get posterior subcapsular cataracts ${ }^{[4]}$.

Our series is unusual in the current literature in having a comparatively large number of patients all of whom received the same management. Wu et al. do report a series of 13 patients, however management was not consistent in all cases with 3 receiving ILM peel in addition to the plasmin assisted vitrectomy compared with 10 receiving the plasmin assisted vitrectomy alone ${ }^{[11]}$. Wu report $11(92 \%)$ of patients gaining 2 lines of vision improvement and six (50\%) achieving 20/50 or better. In our series the mean improvement in vision was LogMar 0.48 or four and half lines with $6(50 \%)$ achieving LogMar 0.5 (20/63) or better.

There have been randomised controlled trials of macular hole closure techniques in adult patients as well as a Cochrane review of these comparing vitrectomy alone with vitrectomy plus ILM peel. This meta analysis took in 4 individual trials of 47,80 , 49 and 141 patients and showed that visual outcomes at 6 and 12 months were no different between the group with ILM peeling than the group without. ILM peeling did however produce a significantly greater rate of primary hole closure, as well as a lower rate of requiring further surgical intervention after the initial operation. For this 
reason the review concluded that ILM peeling may be a cost effective addition to vitrectomy ${ }^{[13]}$. The closure rate of macular holes in our series, $92 \%$, is equal to that of Wu et al in their comparable sized case series of paediatric patients [11]. It is also comparable to the rate of closure found in the Cochrane review of those studies reporting ILM peel in adult macular holes $(90 \%)$ and far better that that of adult macular hole repairs without ILM peel $\left(50 \%\right.$ closure rate) ${ }^{[13]}$.

In conclusion, we present a case series of 13 paediatric patients where macular holes were treated by vitrectomy and internal limiting membrane peel producing successful anatomical closure and good visual outcomes for the majority. These results suggest that it is an efficacious procedure and is comparable to plasminassisted surgery.

References: 
1. NAKANO, T. et al. A nontraumatic macular hole in a 10-year-old girl. Jpn $\mathbf{J}$ Ophthalmol, v. 49, n. 6, p. 520-2, 2005 Nov-Dec 2005. ISSN 0021-5155. Disponível em: <http://www.ncbi.nlm.nih.gov/pubmed/16365800 >.

2. AZEVEDO, S.; FERREIRA, N.; MEIRELES, A. Management of pediatric traumatic macular holes - case report. Case Rep Ophthalmol, v. 4, n. 2, p. 20-7, May 2013. ISSN 1663-2699. Disponível em: < http://www.ncbi.nlm.nih.gov/pubmed/23898288 >.

3. WACHTLIN, J. et al. Long-term results following pars plana vitrectomy with platelet concentrate in pediatric patients with traumatic macular hole. Am J Ophthalmol, v. 136, n. 1, p. 197-9, Jul 2003. ISSN 0002-9394. Disponível em: < http://www.ncbi.nlm.nih.gov/pubmed/12834697 >.

4. MARGHERIO, A. R. et al. Plasmin enzyme-assisted vitrectomy in traumatic pediatric macular holes. Ophthalmology, v. 105, n. 9, p. 1617-20, Sep 1998. ISSN 0161-6420. Disponível em:

$<$ http://www.ncbi.nlm.nih.gov/pubmed/9754166 >.

5. MCCANNEL, C. A. et al. Population-based incidence of macular holes. Ophthalmology, v. 116, n. 7, p. 1366-9, Jul 2009. ISSN 1549-4713. Disponível em: <http://www.ncbi.nlm.nih.gov/pubmed/19576500 >.

6. BRASIL, O. F.; BRASIL, O. M. Management of traumatic macular holes: case report. Arq Bras Oftalmol, v. 71, n. 4, p. 581-4, 2008 Jul-Aug 2008a. ISSN 1678-2925. Disponível em:

<http://www.ncbi.nlm.nih.gov/pubmed/18797673 >.

7. OEHRENS, A. M.; STALMANS, P. Optical coherence tomographic documentation of the formation of a traumatic macular hole. Am $\mathbf{J}$ Ophthalmol, v. 142, n. 5, p. 866-9, Nov 2006. ISSN 0002-9394. Disponível em: < http://www.ncbi.nlm.nih.gov/pubmed/17056374 >.

8. KWOK, A. K. et al. Indocyanine green staining and removal of internal limiting membrane in macular hole surgery: histology and outcome. Am J Ophthalmol, v. 132, n. 2, p. 178-83, Aug 2001. ISSN 0002-9394. Disponível em: < http://www.ncbi.nlm.nih.gov/pubmed/11476676 >.

9. SARTORI, J. E. F.; STEFANINI, F.; MORAES, N. S. Spontaneous closure of pediatric traumatic macular hole: case report and spectral-domain OCT follow-up. Arq Bras Oftalmol, v. 75, n. 4, p. 286-8, 2012 Jul-Aug 2012. ISSN 1678-2925. Disponível em:

< http://www.ncbi.nlm.nih.gov/pubmed/23258664 >.

10. SEBAG, J. Age-related differences in the human vitreoretinal interface. Arch Ophthalmol, v. 109, n. 7, p. 966-71, Jul 1991. ISSN 0003-9950. Disponível em: <http://www.ncbi.nlm.nih.gov/pubmed/2064577 >.

11. WU, W. C. et al. Pediatric traumatic macular hole: results of autologous plasmin enzyme-assisted vitrectomy. Am J Ophthalmol, v. 144, n. 5, p. 668672, Nov 2007. ISSN 0002-9394. Disponível em: < http://www.ncbi.nlm.nih.gov/pubmed/17870044 >.

12. WONG, S. C.; CAPONE, A. Microplasmin (ocriplasmin) in pediatric vitreoretinal surgery: update and review. Retina, v. 33, n. 2, p. 339-48, Feb 2013. ISSN 1539-2864. Disponível em: $<\mathrm{http}: / /$ www.ncbi.nlm.nih.gov/pubmed/23001068 >.

13. SPITERI CORNISH, K. et al. Vitrectomy with internal limiting membrane (ILM) peeling versus vitrectomy with no peeling for idiopathic full-thickness 
macular hole (FTMH). Cochrane Database Syst Rev, v. 6, p. CD009306, 2013. ISSN 1469-493X. Disponível em:

< http://www.ncbi.nlm.nih.gov/pubmed/23740611 >.

Image 1

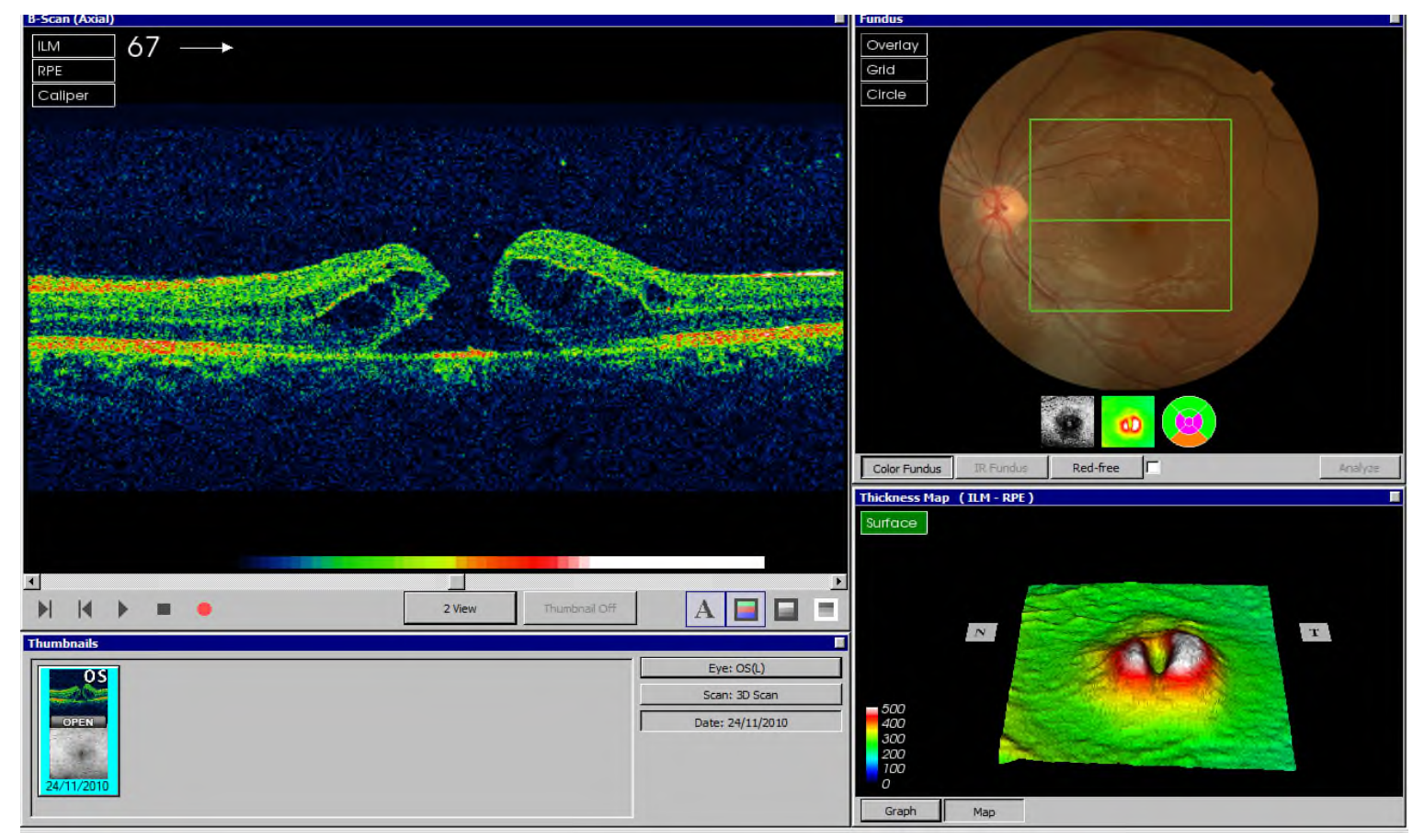

Image 2 


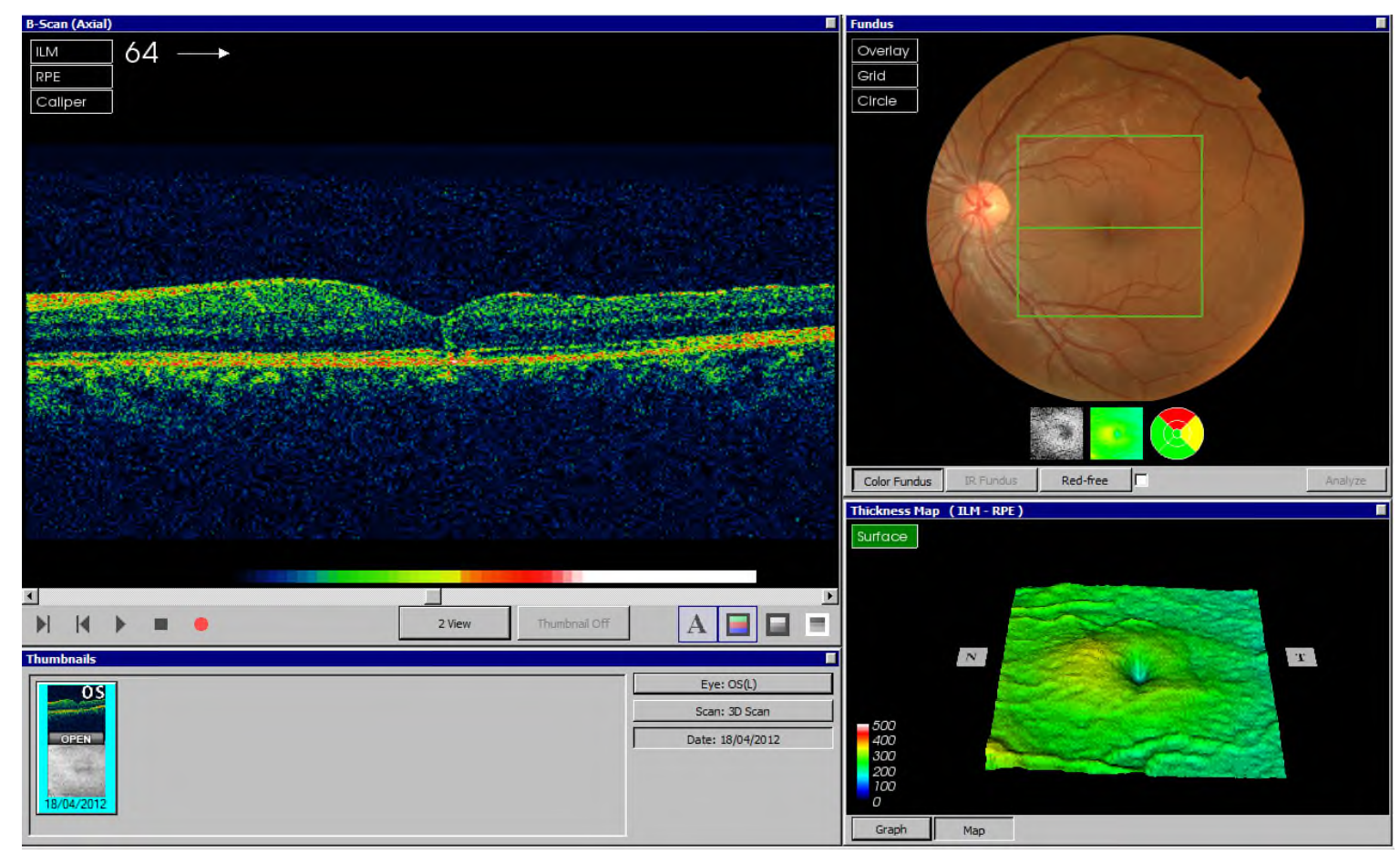




\begin{tabular}{|l|l|l|l|l|l|l|l|l|l|}
\hline Patient & $\begin{array}{l}\text { Age at } \\
\text { surgery }\end{array}$ & $\begin{array}{l}\text { Gen } \\
\text { der }\end{array}$ & Eye & $\begin{array}{l}\text { Nature } \\
\text { of } \\
\text { Trauma }\end{array}$ & $\begin{array}{l}\text { Pre-op } \\
\text { visual } \\
\text { acuity } \\
\text { (LogMa } \\
\text { r) }\end{array}$ & $\begin{array}{l}\text { 3 month } \\
\text { post-op } \\
\text { visual } \\
\text { acuity } \\
\text { (LogMar) }\end{array}$ & $\begin{array}{l}\text { 12 month } \\
\text { post-op } \\
\text { visual } \\
\text { acuity } \\
\text { (LogMar) }\end{array}$ & $\begin{array}{l}\text { Time } \\
\text { from } \\
\text { trauma } \\
\text { to } \\
\text { surgey }\end{array}$ & $\begin{array}{l}\text { Hole } \\
\text { closure }\end{array}$ \\
\hline 1 & 18 & $\mathrm{M}$ & $\mathrm{R}$ & Assault & 1.0 & 0.8 & 0.8 & $2 / 12$ & Yes \\
\hline 2 & 11 & $\mathrm{M}$ & $\mathrm{R}$ & Golf Ball & 0.88 & 0.4 & 0.2 & $6 / 12$ & Yes \\
\hline 3 & 17 & $\mathrm{M}$ & $\mathrm{R}$ & Football & 0.6 & 0.5 & 0.6 & $12 / 12$ & Yes \\
\hline 4 & 11 & $\mathrm{M}$ & $\mathrm{L}$ & Football & 0.6 & 0.1 & 0.2 & $9 / 12$ & Yes \\
\hline 5 & 18 & $\mathrm{~F}$ & $\mathrm{~L}$ & RTA & 1.0 & 0.6 & 0.6 & $7 / 12$ & Yes \\
\hline 6 & 14 & $\mathrm{M}$ & $\mathrm{L}$ & Snowball & 2.28 & 0.66 & 0.66 & $9 / 12$ & Yes \\
\hline 7 & 13 & $\mathrm{M}$ & $\mathrm{R}$ & Football & 0.8 & 0.5 & 0.5 & $1 / 12$ & Yes \\
\hline 8 & 18 & $\mathrm{~F}$ & $\mathrm{R}$ & RTA & 0.8 & 0.6 & 0.6 & $5 / 12$ & Yes \\
\hline 9 & 11 & $\mathrm{M}$ & $\mathrm{L}$ & Football & 0.8 & 0.8 & 0.3 & $5 / 12$ & Yes \\
\hline 10 & 15 & $\mathrm{M}$ & $\mathrm{R}$ & Football & 0.74 & 0.5 & 0.5 & $8 / 12$ & No \\
\hline 11 & 11 & $\mathrm{M}$ & $\mathrm{L}$ & Football & 0.8 & 0.5 & 0.5 & $2 / 12$ & Yes \\
\hline 12 & 12 & $\mathrm{~F}$ & $\mathrm{R}$ & Stone & 0.8 & 0.5 & 0.5 & $3 / 12$ & Yes \\
\hline 13 & 15 & $\mathrm{M}$ & $\mathrm{R}$ & Assault & 0.7 & 0.5 & 0.5 & $1 / 12$ & Yes \\
\hline
\end{tabular}

Figure 1; Patient demographics; site of trauma; nature of trauma; pre-operative visual acuity; post operative visual acuity at 3 months and twelve months. RTA: Road Traffic Accident. VT: Vitrectomy 